\title{
Evaluation of The Effects of Milking Hygiene and Sanitation Education on Total Bacterial and Somatic Cell Number of Bulk Tank Milk in Dairy Cattle Breeding
}

\author{
Ergun Omer Goksoy*1, Sukru Kirkan ${ }^{1}$, Husnu Erbay Bardakcioglu ${ }^{1}$, Selim Sekkin ${ }^{1}$, Devrim Beyaz ${ }^{1}$, \\ Ugur Parin ${ }^{1}$, Fuat Fikret Aktas ${ }^{2}$, İlknur Bogrekci², Ebru Serter ${ }^{2}$, Yasar Meric ${ }^{2}$, Emine Yildiz \\ Kahraman $^{2}$, Pelin Kocak Kizanlik ${ }^{1}$, Cemil Sahiner ${ }^{1}$, Hafize Tugba Yuksel ${ }^{1}$, Solmaz Karaarslan ${ }^{1}$, \\ Reyhan Turkmen ${ }^{3}$, Ciska Anema ${ }^{4}$, Willem Van Der Bent ${ }^{4}$, Ali Ozdes ${ }^{5}$ and Jakub Škaba ${ }^{6}$
}

${ }^{1}$ Adnan Menderes University, Aydin, Faculty of Veterinary Medicine, Turkey; ${ }^{2}$ Aydin Provincial Food Agriculture Animal Husbandry Directorate, Turkey; ${ }^{3}$ Aydin Governorship EU and External Relations Coordination Centre, Turkey; ${ }^{4}$ Dairy Training Centre, The Netherlands; ${ }^{5}$ ÖR-KOOP, Nazilli and Surrounding Agricultural Development Cooperative, Turkey; ${ }^{6}$ Association of Private Farmers, Czech Republic

*Corresponding author: egoksoy@ hotmail.com

Article History: $20-054 \quad$ Received: 02-Mar-20 Revised: $11-\mathrm{Sep}-20 \quad$ Accepted: $16-\mathrm{Sep}-20$
ABSTRA C T
Hygiene and sanitation, which are of great importance for the protection of human. Beside this quality and quantity of
the milk is very important for human health. The aim of this project is to develop a training model in raw milk hygiene
in Aydin province, and to increase knowledge, skills and competencies of vocational/professional groups in raw milk
production. Two surveys were conducted for the farm workers to be trained within the scope of the project. Firstly, a
demonstrative survey was conducted for the farms where milk hygiene training was provided. The education
satisfaction survey was conducted for the people who were educated after the seminar. The surveys were prepared by
the project executives and the questions were answered by face to face interview method. The milk samples of the
study were collected from 157 dairy farm bulk tanks located in Aydin province, before the beginning of the project
and after training courses. The milk samples were analyzed for Total Viable Count (TVC) and Somatic Cell Count
(SCC). In conclusion, $11 \%$ of tank milk samples were below the norm value of $100000 \mathrm{cfu} / \mathrm{mL}$ out of $157 \mathrm{farms.} \mathrm{It} \mathrm{is}$
also seen that 27 farms reduced their SCC values below 400000 cells/mL out of 56 farms with a norm value of
$\geq 400000$ cells $/ \mathrm{mL}$ after hygiene training. When the results were evaluated in general, hygiene was improved by $11 \%$
in average TVC value and $1 \%$ in SCC value after milking hygiene education.

Key words: Bulk Tank Milk, Education, Milk Hygiene, SCC, TVC.

(C2020 IJVS - All Rights Reserved

\section{INTRODUCTION}

Milk has many important properties, for the growth and development of mammals, in the life cycle due to its fatty acids, vitamins and minerals, which are found in its structure. It also contains physiologically important components such as immunoglobulin, enzymes, enzyme inhibitors, growth hormones, antibacterial agents, protein and peptides. Milk and dairy products are considered the most important foodstuffs for living organisms (Maijala 2000; Fox and McWeeney 2003; Miller et al. 2010).

The employment created for each country is the key to the balance of rural development and agriculture, especially in terms of the value of the domestic and export markets it creates. Dairy products take an important place in these markets (Beykaya et al. 2017). About 18 million tonnes of milk are produced annually in Turkey. The $42 \%$ of produced milk reaches the consumer as raw milk. The $40 \%$ of total produced milk are processed in small enterprises and $20 \%$ in large and modern enterprises (Güzel-Seydim and Koçak 2004; TSI 2016). Aydin, where the project has been implemented, is one of Turkey's top milk producers with a national share of $2.5 \%$, and 344 thousand cattle. It has a $4 \%$ share in Turkey-4th in the country-in culture race cattle breeding with a total of 253887 animals, 92260 milked animals and 366 tons of

Cite This Article as: Goksoy EO, Kirkan S, Bardakcioglu HE, Sekkin S, Beyaz D, Parin U, Aktas FF, Bogrekci İ, Serter E, Meric Y, Kahraman EY, Kizanlik PK, Sahiner C, Yuksel HT, Karaarslan S, Turkmen R, Anema C, Bent WVD, Ozdes A and Škaba J, 2021. Evaluation of the effects of milking hygiene and sanitation education on total bacterial and somatic cell number of bulk tank milk in dairy cattle breeding. International Journal of Veterinary Science 10(1): 37-42. https://doi.org/10.47278/journal.ijvs/2020.009 
Int J Vet Sci, 2021, 10(1): 37-42.

milk. There are generally mid-sized and small livestock enterprises in Aydın. In 2014, according to the registry of the Ministry of Food, Agriculture and Livestock Breeding, there were over 46 thousand companies and more than 43 thousand of which were dairy cattle enterprises (TSI 2016).

More than $75 \%$ of the milk produced by the EU countries is collected through cooperatives and other organizations then handed over to industrial establishments in cold chain and hygienic conditions (Ateş 2015). Since milk has a rapid spoiling feature, it must be kept under the special conditions until consumption. The quality of raw milk depends on the first stage of production in the enterprises (Srairi et al. 2009).

Somatic cell count (SCC) and Total Viable Count (TVC) are used as the important criteria in raw milk quality and mammary health issues (Mu'nera-Bedoya et al. 2017). Somatic cells in the milk consist of epithelial cells, large squamous cells, epithelial cell debris and nonnucleated cells, erythrocytes, plasma cells, colostrum corpuscles and leukocytes. High SCC was affected by age of the cow, age of lactation, stress, season, nutrition, observance of hygiene rules and mastitis. The levels of SCC and TVC provide valuable information on the hygienic conditions during various steps of milk production on the farm (Cedden et al. 2002; Eyduran et al. 2005; Macedo et al. 2018; Ginestreti et al. 2020). Consumers need to be able to source raw milk from farmers that have adopted a high level of good animal husbandry practices and manufacturing practices that can reduce potential food safety hazards to very low levels (Berge and Baars 2020; Singhal et al. 2020).

Sustainable Milk Hygiene Training Model for Safe Milk and Safe Future (2015-1-TR01-KA202-022316) project was funded by the European Commission under the Erasmus+ Program. The applicant organizer of project was Aydın Provincial Food Agriculture Animal Husbandry Directorate (Turkey) and the other partners were Aydin Governorship EU and External Relations Coordination Centre (Turkey), Aydin Adnan Menderes University Faculty of Veterinary Medicine (Turkey), ÖR-KOOP (Nazilli and Surrounding Agricultural Development Cooperative) (Turkey), Dairy Training Centre (The Netherlands), Asociace Soukromeho Zemedelstvi Ceske Republiky (Association of Private Farmers, Czechia).

The current situation about milk hygiene in Turkey is far behind the desired level in terms of quality of raw milk. It is now more meaningful to make safe and quality production because of the reasons such as the developing economic conditions; the level of consumer consciousness and the sharing of technological information reach the upper level. In terms of the quality and safe product, hygienic principles have become the most important criteria. In close collaboration with the relevant partners, we have planned to develop training modules, written and visual training materials, to implement series of training courses to increase awareness, knowledge, skills and competencies for raw milk hygiene.

The aim of this study was to prepare a training model for milk hygiene, to increase the expertise and skills of vocational/professional groups in the raw milk production sector and to bring raw milk production to EU standards in terms of hygiene criteria.

\section{MATERIALS AND METHODS}

\section{Analysis of Survey Data}

Two surveys were conducted for the farm workers to be trained within the scope of the project. Firstly, a demonstrative survey was conducted for the farms where milk hygiene training would be provided. The education satisfaction survey was conducted for the people who were educated after the seminar. The both surveys were prepared by the project executives and the questions were answered by face to face interview method. Before the application, the personnel who were planned to conduct the survey, the purpose of the study was explained. After the reliability test was applied to the surveys, the statistical analyses were done. The population of surveys were the dairy cattle farms of Aydin-Turkey. A survey was given to 150 enterprises selected by random sample method before training, and the satisfaction survey after training was applied to 274 people working in these enterprises. Pre-training survey consist of three subdimensions as; General Information about farms and milk parlor staff, information about milking practices at farms, and information related to parlor hygiene. A total of 60 questions were asked in these three sections. The posttraining satisfaction survey consisted of three subdimensions; Training Planning and Implementation, Educators and Training results. In these factors, 32 questions were asked to participants. The items in the survey were presented as options using the Likert scale of 5 , and according to the average of the responses given to the survey items, the following interval values were interpreted: 1.00-1.79: strongly disagree, 1.80-2.59: disagree, 2.80-3.39: Have no idea, 3.40-4.19: agree, 4.205.00: strongly agree. Quantitative analyses were conducted by using SPSS software version 22. Descriptive analyses were presented using means, standard error of means and percentages. Exploratory factor analysis using principalcomponents analysis was carried out as recommended by Pallant (2007). The Kaiser-Meyer-Olkin measure of sampling adequacy and Bartlett's test of sphericity confirmed. Cronbach's Alpha coefficient was used to determine the reliability of the survey.

\section{Milk Samples}

Milk samples were collected from 157 dairy farms located in Aydın Districts (Çine: 35, Efeler: 25, Germencik: 7, Karpuzlu: 26, Koçarlı: 29, Söke: 5, Kuyucak: 14, Nazilli: 16), before the beginning of the project and after training courses.

Raw milk samples $(500 \mathrm{~mL})$ were collected from isothermal bulk tanks at a temperature lower than $5^{\circ} \mathrm{C}$ into the sterile bottles by specially educated technicians 3 times within 2 weeks intervals, at the beginning of the project (Sample 1 group) and after the trainings (Sample 2 group). The samples were labelled and transported in cold chain to Aydin Adnan Menderes University, Faculty of Veterinary Medicine, Department of Food Hygiene and Technology laboratory. The distribution of the total number of samples analyzed by districts was shown in Table 1 .

\section{Microbiological Examination}

The milk samples collected from in bulk tank, $25 \mathrm{~mL}$ was taken and homogenized in $225 \mathrm{~mL}$ of peptone water 
(Oxoid CM0009) using a Lab-Blender 400 Stomacher (Interscience, France) for at least two minutes in order to enumerate TVC. Decimal serial dilutions were prepared.

\section{Total Viable Count (TVC) and Somatic Cell Count (SCC)}

The prepared decimal dilutions of raw milk samples inoculated onto Plate Count Agar (Oxoid CM0325), for TVC after incubation at $30^{\circ} \mathrm{C}$ for $48-72$ hours (Maturin and Peeler 2001). SSC of milk samples were determined by NucleoCounter® SCC-100 ${ }^{\mathrm{TM}}$ (Chemometec, Denmark).

\section{Statistical Analysis}

Statistical analyses were performed using the SPSS software version 22.0. The data were presented as the mean and standard deviation (SD) for the item statistic of the survey results; while mean and standard error of mean (SE) for descriptive results.

Milk samples were grouped as $\geq 100000 \mathrm{cfu} / \mathrm{mL}$ and $<100000 \mathrm{cfu} / \mathrm{mL}$ for TVC and $\geq 400000$ cells $/ \mathrm{mL}$ and $<400000$ cells $/ \mathrm{mL}$ for SCC. The proportions of TVC and SCC groups presented as percentages at the beginning of the education (pre-education) and at the end of the education (post-education) of the staff. The McNemarchisquare test was used to compare these proportions between pre-education and post-education of the staff. $\mathrm{P}<0.05$ was considered to show a statistically difference.

\section{RESULTS}

\section{Survey Results}

Cronbach's Alpha reliability values determined as a result of the reliability test on the first and second survey data collected within the scope of the study were calculated as 0.872 and 0.895 , respectively. These values are above the absolute limit values suggested by Nunnally (1978), so the answers to the surveys can be said to be reliable. General survey descriptive results presented on Table 2. Majority $(68 \%)$ of the survey participants was graduated from elementary school, while $25.3 \%$ graduated from secondary school and the others (4\%) graduated from higher schools. Survey participants mentioned three main subjects about farm types as family farms, individual private farms and partnership private farms. Proportion of these farms were $60.7,36.0$ and $3.3 \%$, respectively. Participant farms had six different types of barns as open air $(40.0 \%)$, open air free stall $(0.7 \%)$, semi-open $(32.7 \%)$, semi-open free stall $(23.3 \%)$, closed $(0.7 \%)$ and closed free stall $(2.7 \%)$. Using portable milking machine proportion was $83.3 \%$ while using fixed milking machine was $14.0 \%$ and by hand milking was $2.7 \%$.

Table 1: Total number of samples distribution by districts

\begin{tabular}{lccc}
\hline District of the farm & $\begin{array}{c}\text { Farm } \\
\text { Number }\end{array}$ & $\begin{array}{c}1 \text { st } \\
\text { Sampling }\end{array}$ & $\begin{array}{c}\text { 2nd } \\
\text { Sampling }\end{array}$ \\
\hline Çine & 35 & 105 & 105 \\
Efeler & 25 & 75 & 75 \\
Germencik & 7 & 21 & 21 \\
Karpuzlu & 26 & 78 & 78 \\
Koçarlı & 29 & 87 & 87 \\
Söke & 5 & 15 & 15 \\
Kuyucak & 14 & 42 & 42 \\
Nazilli & 16 & 48 & 48 \\
\hline Total number of samples analyzed & 471 & 471 \\
\hline
\end{tabular}

The Likert scale averages of the survey before milking hygiene education were varied between 2.16 (teat dipping was done before each milking) and 4.44 (the milking process was carried out on a regular basis). Survey items answer averages and interpretations were shown in Table 3.

Training satisfaction survey was done for 274 participants. The distribution of the participants according to the Çine, Efeler, Germencik, Karpuzlu, Koçarlı and Söke districts were 27.7, 36.5, 4.0, 18.2, 9.5, and 4.0\%, respectively. Majority of the participants (94.9\%) were male, while $5.1 \%$ were female. Educational status of the participants distributed as graduated from elementary school $(76.3 \%)$, graduated from secondary school $(20.4 \%)$ and graduated from higher school (3.3\%). One-fourth $(24.1 \%)$ of the participants had education before the milk hygiene education course and rest of them (75.9\%) did not have any hygiene education.

The Likert scale averages of the training satisfaction survey after milking hygiene education were varied between 4.31 (the duration of the training was sufficient) and 4.70 (educators had enough communication with the participants). Survey items answer averages and interpretations were shown in Table 4.

\section{Microbiological Results}

The results of the microbiological analysis (TVC) and SCC of milk samples before and after hygiene training were given in Table 5. The data obtained according to TVC norm values for some of the farms constituting the research material were shown in Table 6 . As seen in Table 6, 143 farms were found above $100000 \mathrm{cfu} / \mathrm{mL}$ norms before milk hygiene education and the TVC value of 12 of the farms dropped to $100000 \mathrm{cfu} / \mathrm{mL}$ after the training. At the same time, while 14 farms with $<100000 \mathrm{cfu} / \mathrm{mL}$ norm values before education, 9 of them exceeded $100000 \mathrm{cfu} / \mathrm{mL}$ after hygiene education. In total, $17(11 \%)$ of samples were below $100000 \mathrm{cfu} / \mathrm{mL}$ norm values after the education. There were no significant difference between pre and post education TVC ratios $(\mathrm{P}>0.05)$ The data regarding to the SCC values obtained from the farms were shown in Table 7.

As shown in Table 7, 56 farms with a norm value of $\geq 400000$ cells $/ \mathrm{mL}$ in this study showed SCC values below 400000cells $/ \mathrm{mL}$ in 27 farms after hygiene training, whereas 30 of 101 farms with a value of $<400000$ cells $/ \mathrm{mL}$ were detected above 400000 cells $/ \mathrm{mL}$ norm value. There were no statistical significant difference found between pre and post education SCC percentage changes $(\mathrm{P}>0.05)$. The distribution of TVC values obtained from districts after hygiene education were shown on Table 8 . When the distribution according to the districts was examined, TVC values decreased by $65(41.4 \%)$ indices of 157 farm milk samples.

Table 2: Survey descriptive results of the sample farms before milking hygiene education

\begin{tabular}{lcr}
\hline & $\mathrm{N}$ & \multicolumn{1}{c}{ Mean $\pm \mathrm{SE}$} \\
\hline Average Milk Production per cow (kg) & 144 & $20.40 \pm 0.41$ \\
Age of the Employee & 148 & $45.71 \pm 0.97$ \\
the number of people in the family & 141 & $3.79 \pm 0.12$ \\
Employee number working in milking parlor & 150 & $1.53 \pm 0.04$ \\
Milking Parlor Capacity (head/cow) & 38 & $5.37 \pm 0.80$ \\
\hline
\end{tabular}


Int J Vet Sci, 2021, 10(1): 37-42.

Table 3: Item Statistics (Before Milking Hygiene Education, n: 150)

\begin{tabular}{lll}
\hline & Mean \pm SD & Interpretation \\
\hline Barn cleaning is done on a regular basis & $3.94 \pm 0.84$ & Agree \\
The farm is well usefulness & $4.03 \pm 0.93$ & Agree \\
Barn ventilation is good & $4.22 \pm 0.87$ & strongly agree \\
Barn lighting is good & $4.09 \pm 0.96$ & Agree \\
The cleanliness of the cows is good & $4.00 \pm 0.67$ & Agree \\
The feeding of the cows are regularly held & $4.31 \pm 0.78$ & strongly agree \\
water quality is given to the cows & $4.09 \pm 0.99$ & Agree \\
Manure is cleaned every day & $3.19 \pm 1.42$ & have no idea \\
Cow density is sufficient & $4.22 \pm 0.83$ & strongly agree \\
Milking parlor cleaning is done every day & $4.19 \pm 0.96$ & Agree \\
Milking parlor usability is good & $3.97 \pm 1.25$ & Agree \\
Milking parlor ventilation is good & $4.13 \pm 0.97$ & Agree \\
Milking parlor lightning is good & $4.00 \pm 1.04$ & Agree \\
The milking process is carried out on a regular basis & $4.44 \pm 0.56$ & strongly agree \\
Milking rules are applied to the milking parlor & $4.25 \pm 0.71$ & strongly agree \\
Parlor employees comply with the rules of hygiene & $4.06 \pm 0.75$ & Agree \\
udder and teats are controlled before each milking & $4.13 \pm 1.12$ & Agree \\
Each cow's teats are cleaned before each milking & $4.09 \pm 1.14$ & Agree \\
Teat dipping is done before each milking & $2.16 \pm 1.46$ & Disagree \\
Teat dipping is done after each milking & $2.41 \pm 1.58$ & Disagree \\
Cows udder dried after each cleaning & $2.31 \pm 1.53$ & Disagree \\
Udder is checked after milking & $3.97 \pm 1.44$ & Agree \\
\hline
\end{tabular}

Table 4: Item Statistics (After Milking Hygiene Education)

\begin{tabular}{lr}
\hline & Mean \pm SD \\
\hline The duration of the training was sufficient & $4.31 \pm 0.84^{*}$ \\
Education content was adequate & $4.39 \pm 0.72^{*}$ \\
Topics were clear and understandable & $4.51 \pm 0.62^{*}$ \\
The training material was sufficient & $4.40 \pm 0.76^{*}$ \\
Explanation for purpose was made & $4.55 \pm 0.69^{*}$ \\
Subjects presented with appropriate methods & $4.58 \pm 0.62^{*}$ \\
Active participation enabled & $4.49 \pm 0.67^{*}$ \\
Educators had enough communication with the $4.70 \pm 0.51^{*}$ \\
participants & $4.60 \pm 0.59^{*}$ \\
Education given with samples & \\
Education contributed professional development $4.46 \pm 0.70^{*}$ \\
positively & $4.41 \pm 0.75^{*}$ \\
Education gave new knowledge & $4.38 \pm 0.75^{*}$ \\
Education gave practical information & $4.49 \pm 0.73^{*}$ \\
Gained information will be useful & $4.68 \pm 0.54^{*}$ \\
Theoretical knowledge applied & $4.55 \pm 0.58^{*}$ \\
Examples used in training were useful
\end{tabular}

*All parameters strongly agree.

The distribution of SCC values obtained from districts after hygiene education were shown on Table 9. When the distribution according to the provinces was examined, it was found that the SCC values of 79 (50.3\%) of 157 farm milk samples decreased.

\section{DISCUSSION}

Due to its complex biochemical structure and highwater capacity, raw milk is an excellent medium for microorganisms. Some of these microorganisms, mainly total viable mesophilic microorganisms, are indicators in determining the hygienic properties, both in the protection of milk quality and in the process from raw milk production to consumption (Üzüm 2006).

The acceptable numbers of SCC in the raw milk have been determined by the relevant authorities in EU, and Health and Hygiene Directive (92/46/EEC) requires raw milk SCC should not exceed 400000 cell $/ \mathrm{mL}$ (Europa 1992). According to the Turkish Food Codex (2009) on Raw Milk and HeatTreated Milks, raw cow milk should contain less than $100000 \mathrm{cfu} / \mathrm{mL}$ TVC and less than 400000cell/mL SCC.

Mastitis is one of the most important problems of herd management. Determination of mastitis status of herd is carried out via somatic cell count taken from the tank milk. If tank milk SCC is low, but there are a lot of clinical cases, it is concluded that the problem is environmental, whereas if SCC is high but the number of clinical cases is low, it is concluded that the problem is contagious (Mingala et al. 2020).

The high level of SCC in mastitic milk cause changes in milk enzymes and results in the breakdown of proteins and fats. One of these enzymes, plasmin, increases the breakdown of casein due to the increase in SCC which reduces casein level in the milk. This disruption begins with SCC rising above 100000 cells $/ \mathrm{ml}$. Depending on the changes in the milk composition in, the quality of the cheese cloth reduces during the production of cheese. Increased activity of proteolytic enzymes in high somatic cell reduces the amount of product and causes impaired aroma (Kirk 2005; Elbayoumy et al. 2020).

In this study, it was determined that the mean TVC and SCC values obtained before the milking hygiene training were above the norm values. As a result of the milking hygiene training given to the farm workers, the laboratory analyses showed that the average TVC and SCC values decreased. 143 farms were found above $100000 \mathrm{cfu} / \mathrm{mL}$, and after the milk hygiene training, the TVC value of 12 farms was lowered to $100000 \mathrm{cfu} / \mathrm{mL}$. It is also observed that 14 farms with norm values of $<100000 \mathrm{cfu} / \mathrm{mL}$ exceeded higher than $100000 \mathrm{cfu} / \mathrm{mL}$ norm values after training. In conclusion, 17 (11\%) of tank milk samples were below the norm value of $100000 \mathrm{cfu} / \mathrm{mL}$ out of 157 farms. 27 farms reduced their SCC values below 400000 cells $/ \mathrm{mL}$ out of 56 farms with a norm value of $\geq 400000$ cells $/ \mathrm{mL}$ after hygiene training, whereas 30 of 101 farms with a value of $<400000$ cells $/ \mathrm{mL}$ exceeded 400000cells $/ \mathrm{mL}$. When overall results were evaluated, hygiene was improved by $11 \%$ in TVC value and $1 \%$ in SCC value after training. 
Int J Vet Sci, 2021, 10(1): 37-42.

Table 5: The descriptive statistical data of the mean values

\begin{tabular}{lllll} 
& N & Min & Max & Mean \pm SE \\
\hline Pre-Education TVC Value $(\mathrm{cfu} / \mathrm{mL})$ & 157 & 11000 & 6305000 & $1067528.02 \pm 96685.59$ \\
Post-Education TVC Value $(\mathrm{cfu} / \mathrm{mL})$ & 157 & 14000 & 11089333 & $946026.00 \pm 104772.47$ \\
Pre-Education SCC Value $(\mathrm{cell} / \mathrm{mL})$ & 157 & 10000 & 1826333 & $401512.84 \pm 29828.83$ \\
Post-Education SCC Value $(\mathrm{cell} / \mathrm{mL})$ & 157 & 10000 & 2000000 & $397728.23 \pm 30922.27$ \\
\hline
\end{tabular}

Table 6: TVC Cross tabulation [n (\%)]

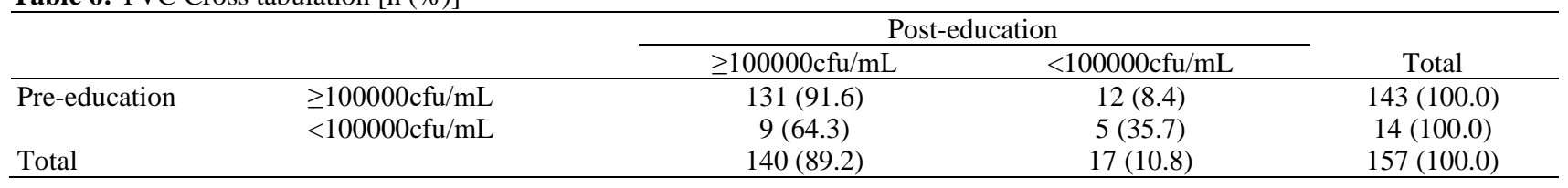

Table 7: SCC Cross tabulation [n (\%)]

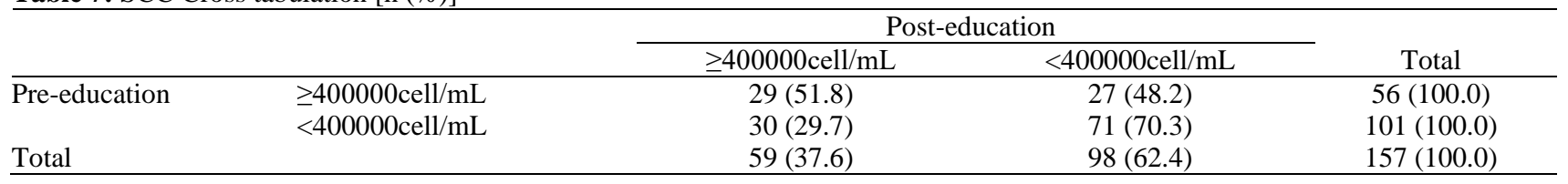

Table 8: Number of farms about TVC changing after education according to the districts [n (\%)]

\begin{tabular}{|c|c|c|c|}
\hline District & Increased or not changed & Decreased & Total \\
\hline Çine & $26(76.5)$ & $8(23.5)$ & $34(100.0)$ \\
\hline Efeler & $16(64.0)$ & $9(36.0)$ & $25(100.0)$ \\
\hline Germencik & $4(57.1)$ & $3(42.9)$ & $7(100.0)$ \\
\hline Karpuzlu & $14(53.8)$ & $12(46.2)$ & $26(100.0)$ \\
\hline Koçarlı & $19(63.3)$ & $11(36.7)$ & $30(100.0)$ \\
\hline Kuyucak & $6(42.9)$ & $8(57.1)$ & $14(100.0)$ \\
\hline Nazilli & $6(37.5)$ & $10(62.5)$ & $16(100.0)$ \\
\hline Söke & $1(20.0)$ & $4(80.0)$ & $5(100.0)$ \\
\hline TOTAL & $92(58.6)$ & 65 (41.4) & $157(100.0)$ \\
\hline
\end{tabular}

Table 9: Number of farms about SCC changing after education according to the districts [n (\%)]

\begin{tabular}{llll}
\hline District & Increased or not changed & Decreased & Total \\
\hline Çine & $21(61.8)$ & $13(38.2)$ & $34(100.0)$ \\
Efeler & $17(68.0)$ & $8(32.0)$ & $25(100.0)$ \\
Germencik & $2(28.6)$ & $5(71.4)$ & $7(100.0)$ \\
Karpuzlu & $14(53.8)$ & $12(46.2)$ & $26(100.0)$ \\
Koçarlı & $11(36.7)$ & $19(63.3)$ & $30(100.0)$ \\
Kuyucak & $7(50.0)$ & $7(50.0)$ & $14(100.0)$ \\
Nazilli & $5(31.3)$ & $11(68.8)$ & $16(100.0)$ \\
Söke & $1(20.0)$ & $4(80.0)$ & $5(100.0)$ \\
TOTAL & $78(49.7)$ & $79(50.3)$ & $157(100.0)$ \\
\hline
\end{tabular}

Values in parenthesis indicate $\%$.

In a previous study, 6.04logcells $/ \mathrm{mL} ; 6.60 \log$ cells/ $\mathrm{mL} ; 6.09 \log$ cells $/ \mathrm{mL} ; 6.25 \log$ cells $/ \mathrm{mL}$ and $6.83 \log$ cells/

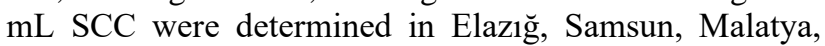
Şanlıurfa and Erzurum provinces. All the analyzed samples showed higher value than 100000 cells/mL. 11 of the samples $(2.5 \%)$ were between 100000500000 cells $/ \mathrm{mL}, 139$ of them $(31.6 \%)$ were between $500000-1000000$ cells $/ \mathrm{mL}$ and 290 of them $(65.9 \%)$ had SCC value more than 100000 cells/mL (Patır et al. 2010).

Akın et al. (2016) reported that TVC in farm milk was 5.24-5.74logcfu/mL and that TVC in collectors' milk was 6.45-7.01logcfu/mL. Diler and Baran (2014) found that TVC of tank milk were between 2.8 and $6.8 \log \mathrm{cfu} / \mathrm{mL}$ and $36.7 \%$ of the samples met the criteria stated in the Turkish Food Codex (2009).

To be able to process high quality milk and dairy products, the hygienic quality of the processing steps (animal health and care, hygiene in stall, udder cleaning, cleaning and disinfection of milking machines, equipment etc.) should be improved. In this manner, milking hygiene trainings for farm workers are of great importance. Naing et al. (2018) stated that in order to improve milk quality, farmers should be trained properly.

In this study a total of 1400 farm workers were trained in milking hygiene by specialist trainers, then educational evaluation surveys were conducted. Milk samples were also collected from the farms where the training was conducted, and TVC and SCC values were determined. As results showed that TVC values decreased in $65(41.4 \%)$ farms and SCC values decreased in 79 $(50.3 \%)$ farms out of 157 farms. It was concluded that the training was effective on the basis of the districts and envisaged hygiene procedures should be implemented to ensure the sustainability of hygiene in farms. A study conducted by Mu'nera-Bedoya et al. (2017), aimed to find out how human behaviors affect the milk process also concluded that SCC was associated to knowledge of animal handling, training of milkers, and milking site.

\section{Conclusion}

Milk quality is an important issue in the commercial area as the farmer who produces high quality milk sells it with higher price and gains more profit. While the factories produce high quality dairy products using high quality milk, the demand of consumer to these products increases. Therefore, increasing milking hygiene by improving the farmers' knowledge and changing their attitudes by training would be crucial for healthy milk and dairy products.

\section{Acknowledgements}

This article was prepared under the main Action 2 2015 Year Vocational Training Strategic Partnership Project "Sustainable Milk Hygiene Training Model for Safe Milk and Safe Future (2015-1-TR01-KA202022316)" funded by the European Commission under the ERASMUS+ program. However, the European Commission and the Turkish National Agency cannot be held responsible for the opinions contained here.

\section{REFERENCES}

Akin MS, O Yapik and MB Akin, 2016. Some properties of raw milk obtained from dairy production farm and collectors in 
Adiyaman. Harran Journal of Agricultural and Food Science 20: 253-265.

Ates R, 2015. A Research: Determination of changes in the composition of raw milk provided from private farms and association of manufacturers in different region of Turkey all the year round. MSc thesis, Namık Kemal University, Institute of Natural and Applied Science, Food Engineering Department, Tekirdag, Turkey, pp: 41.

Berge AC and Baars T, 2020. Raw milk producers with high levels of hygiene and safety. Epidemiology and Infection 148: 1-7. https://doi.org/10.1017/S0950268820000060

Beykaya M, A Ozbey and Z Yildirim, 2017. Determination of physical, chemical and microbiological properties of milk from some dairy plants in Sivas Province. Turkish Journal of Agriculture-Food Science and Technology 5: 388-396. https://doi.org/10.24925/turjaf.v5i4.388-396.1172

Cedden F, A Kor and S Keskin, 2002. Somatic cell counts in goat milk during late lactation period and its relationship with milk yield, age and some udder measurements. Yuzuncu Yil University Journal of Agricultural Sciences 12: 63-67.

Diler A and A Baran, 2014. Determination of some quality characteristics of raw cow milk on small holder dairy farms in Hinis district of Erzurum. Alinteri Journal of Agricultural Sciences 26: 18-24.

Elbayoumy MK, AM Allam, ST Omara, EA Elgabry, SS Abdelgayed, 2020. Role of artesunate in potentiation of $\beta$ lactam against methicillin resistant Staphylococcus aureus (MRSA) isolated from bovine mastitis and its histopathology impact in-vivo study. International Journal of Veterinary Science 9: 337-342.

Europa EU, 1992. Animal Health and Welfare. http://europa.eu/eur-lex/en/consleg/\%20pdf/1992/en_1992 L0046_do_001.pdf. [access: 08.2017]

Eyduran E, T Ozdemir, K Yazgan and S Keskin, 2005. The effects of lactation rank and period on somatic cell count (SCC) in milks of Holstein cows. Van Veterinary Journal 16: 61-65.

Fox PF and PLH McWeeney, 2003. Milk proteins: General and historical aspects. In: Advanced Dairy Chemistry. 3rd Ed, Springer Verlag Publish, New York, USA, pp: 1-48.

Ginestreti J, Strano RM, Lorenzi V, Fusi F, Angelucci A, Ferrara G, Galletti G, Bergagna S, Bolzoni G, Zanardi G, Buffoli E, Marcolini A and Bertocchi L, 2020. Bulk tank milk quality data is unlikely to give useful information about dairy cow welfare at herd level. Journal of Dairy Research 87: 208-211. https://doi.org/10.1017/ $\underline{\text { S0022029920000187 }}$

Güzel-Seydim ZB and C Kocak, 2004. The scope of Turkish dairy before European Union accession. Proc "International Dairy Symposium”, Isparta, Turkey, 24-28 May, 2004, pp: 5-9.

Kirk JH, 2005. The effect of poor quality raw milk on finished products. Extension Veterinarian School of Veterinary Medicine University of California Davis Tulare, CA. http://cesacramento.ucdavis.edu.Dairy/main.pdf [access:08.2017].
Macedo SN, GonÇalves JL, Cortinhas CS, Leite RF and Santos MV, 2018. Effect of somatic cell count on composition and hygiene indicators of bulk tank milk. Brazilian Journal of Veterinary Research and Animal Science 55: 1-11. https://doi.org/10.11606/issn.1678-4456.bjvras.2018. 133413

Maijala K, 2000. Cow milk and human development and wellbeing. Livestock Production Science 65: 1-18. https://doi.org/10.1016/S0301-6226(00)00194-9

Maturin L and JT Peeler, 2001. Aerobic Plate Count. In: FDA's Bacteriological Analytical Manual $8^{\text {th }}$ Ed, Revision A, Chapter 3. https://www.fda.gov/Food/FoodScience Research/LaboratoryMethods/ucm063346.htm [access:01.2015].

Miller GD, KJ Jarvis and LD McBean, 2010. The importance of milk and milk products in the diet, in: Miller GD, Jarvis JK and Mcbean LD (editors), Handbook of Dairy Foods and Nutrition. 3rd Ed, CRC Press, New York, USA, pp: 4-24.

Mingala CN, Wy AMP, Cruz DGD, Ermitanio ED, Gaban PBV and Castro DFP, 2020. Alpha-2-Macroglobulin gene polymorphism in water buffaloes (Bubalus bubalis) with subclinical mastitis. International Journal of Veterinary Science 9: 116-120.

Múnera-Bedoya OD, Cassoli LD, Machado P and CerónMuñoz F, 2017. Influence of attitudes and behavior of milkers on the hygienic and sanitary quality of milk. PLoS ONE 12: 1-13. https://doi.org/10.1371/journal. pone. 0184640

Naing YW, Wai SS, Lİn TN, Thu WP, Htun LL, Bawn S and Myain TT, 2019. Bacterial content and associated risk factors influencing the quality of bulk tank milk collected from dairy cattle farms in Mandalay Region. Food Science \& Nutrition 7: 1063-1071. https://doi.org/10.1002/fsn3.945

Nunnally JC, 1978. Psychometric Theory, 2nd Ed, McGraw-Hill Book Company, New York, USA.

Pallant J, 2007. SPSS Survival Manual: A step by step guide to data analysis using SPSS for Windows. $1^{\text {st }}$ Ed, Open University Press, Maidenhead, England, pp: 257-266.

Patır B, OP Can and M Gürses, 2010. Somatic cell counts in raw cow milk collected from different city. Frrat University Veterinary Journal of Health Science 24: 87-91.

Sraïri MT, H Benhouda, M Kuper and PY Le Gal, 2009. Effect of cattle management practices on raw milk quality on farms operating in a two-stage dairy chain. Tropical Animal Health and Production, 41: 259-272. https://doi.org/ 10.1007/s11250-008-9183-9.

Singhal P, Kaushik G, Hussain CM and Chel A, 2020. Safety Issues in Beverage Production. Chapter 12: Food safety issues associated with milk: a review. 399-427. https://doi.org/10.1016/B978-0-12-816679-6.00012-7

TSI, 2016. Turkish Statistical Institute, Ankara, Turkey. http://www.tuik.gov.tr [access: 08.2016].

Turkish Food Codex, 2009.Turkish Food Codex Communique on Raw Milk and Heat-Treated Drinking Milk 06.02.2009/27133, No: 2009-14.

Üzüm M, 2006. The isolation of some pathogens and Salmonella-Shigella in the raw milk sold in Ankara area. MSc thesis, Gazi University, Institute of Science and Technology, Ankara, Turkey, pp: 73. 